\title{
Role of public entrepreneurship in the progress of agricultural produces in Himalayas.
}

\section{Papel del espíritu empresarial público en el progreso de los productos agrícolas en el Himalaya.}

\author{
Imtiyaz Rasool Parrey* \\ * Department of Chemistry, Government Women College Anantnag Jammu and Kashmir pin \\ 1992210 Mob: +91-9797855613
}

\begin{abstract}
Villagers living in the Western Himalayan region of Uttarakhand are primarily dependent upon subsistence farming. They follow the practice of growing crops and raising livestock sufficient only for one's own use, without any surplus for trade. With the growing financial needs of the villagers, some portion of their produces is now readily available for marketing. While doing so a farmer gets easily entrapped into the web of the middleman, who provides him anticipatory loans in lieu of the agricultural produces grown by him and a promise to handover those produces at a much lower prices. Under this process farmers are totally debarred from getting a real fair price for their agricultural produces which otherwise they could have fetched in the absence of a middleman. This paper showcases a real experiment done by one of the authors of this paper in which a Farmer's Producer Organization was established with hundreds of local farmers. Farmer's Producer Organization is ensuring true monetary value for their agricultural produces by eliminating middleman and ensuring value addition to their produces. This paper critically analyses a case of formation of a Farmer's Producer Organization in Mukteshwar area of District Nainital, Uttarakhand. Paper also throws light over its working and the challenges being faced by new generation Farmers.
\end{abstract}

Key Words: Traditional farming, Framer's Producer Organization, Middleman, Livelihood security.

\section{RESUMEN}

Los aldeanos que viven en la región occidental de Uttarakhand en el Himalaya dependen principalmente de la agricultura de subsistencia. Siguen la práctica de cultivar y criar ganado suficiente solo para uso propio, sin ningún excedente para el comercio. Con las crecientes necesidades financieras de los aldeanos, una parte de sus productos está ahora disponible para su comercialización. Al hacerlo, un agricultor queda atrapado fácilmente en la red del intermediario, que le proporciona préstamos anticipados en lugar de los productos agrícolas que cultiva y la promesa de entregar esos productos a precios mucho más bajos. En virtud de este proceso, los agricultores están totalmente excluidos de obtener un precio justo 
Sustainability, Agri, Food and Environmental Research, (ISSN: 0719-3726), 9(2), 2021: 297-310 http://dx.doi.org/10.7770/safer-V0N0-art2333

real por sus productos agrícolas, que de otro modo podrían haber obtenido en ausencia de un intermediario. Este documento muestra un experimento real realizado por uno de los autores de este documento en el que se estableció una Organización de Productores Agrícolas con cientos de agricultores locales. Farmer's Producer Organization está asegurando un verdadero valor monetario para sus productos agrícolas al eliminar a los intermediarios y garantizar el valor agregado a sus productos. Este artículo analiza críticamente un caso de formación de una organización de productores agrícolas en el área de Mukteshwar del distrito de Nainital, Uttarakhand. El papel también arroja luz sobre su funcionamiento y los desafíos que enfrentan los agricultores de nueva generación.

Palabras clave: agricultura tradicional, organización de productores de Framer, intermediario, seguridad de los medios de vida.

\section{INTRODUCTION}

The Farmer Producer Organization have emerged as an alternative for increasing market potential and reducing transaction cost through collective action. The Indian's National Bank for Agriculture \& Rural Development (NABARD) has defined a Farmer Producer Organization as a type of Producer Organization where the members are mainly farmers. It could be established as a company, society or trust. An FPO, formed by a group of farm producers, is a registered body with producers as shareholders in the organization. It deals with business activities related to the farm produce and it works for the benefit of the member producers.

Those FPOs which are set up as Farmer Producer Company (FPC) enable their members to access financial and other inputs and services, including appropriate technologies for farming. The FPCs also organize collection, processing, storage and marketing of their members' produce in high-value markets at an optimal price. Most of the FPOs in India are supported by National Bank for Agriculture \& Rural Development (NABARD). Amongst them $71 \%$ are working as companies, followed by $22 \%$ as co- operatives and $7 \%$ as trust. Regardless of the difficulties in establishing and running Farmer Producer Companies, larger number of FPOs in this legal status could be due to the policies and support provided to encourage FPO while working as a FPC.

A Producer Company (PC) is a legal group of the producers of agricultural produce, forest produce, artisanal products, or any other local produce, where the members are primary producers. PC as a legal entity was enacted in 2003 as per section IXA of the Indian Companies Act 1956. Since then the PC has been addressed as the organizational form that will empower and improve the bargaining power, net incomes, and quality of life of small and marginal farmers and producers in India. Producers organization not only help farmers buy or sell better due to scale benefits but also lower transaction costs for sellers and buyers, providing technical help in production and creating social capital.

With the amendment of the Companies Act 1956 in 2002, the Indian government introduced the concept of 'producer companies', which constitute an attempt to establish basic business principles within farming communities, to bring industry and agriculture closer together, and to boost rural development (Kumar Sharma, 2008). Government of India in 2013 formulated a policy guideline for Farmer Producer Organisations (FPOs). It put forth the 
Sustainability, Agri, Food and Environmental Research, (ISSN: 0719-3726), 9(2), 2021: 297-310 http://dx.doi.org/10.7770/safer-V0N0-art2333

role of centre and state government in promoting FPOs and declared FPOs at-par with cooperatives. Small Farmer Agri Business Consortium (SFAC), a registered body, was made as a nodal agency for promoting FPOs in India. Later, NABARD started promotion of FPOs using their Producers' Organization Development and Upliftmant Corpus Fund.

Such is a case of one of the FPOs in Uttarakhand named as Mukteshwar Farmer Producer Company in the District of Nainital. One of the writers of this paper being an active part of this could closely observe and understand the functioning, challenges, scope of improvement and current situation of Mukteshwar Farmer Producer Company.

Facilitated by the Central Himalayan Rural Action Group, the concept of self-reliant cooperatives with over 710 farmers was set up in 2014 to encourage the agri-marketing at a large scale and benefit the farmers directly. The concept behind its formation was to break the convention of mediators in the agriculture supply chain by providing a direct link between farmers and buyers and therefore offering better perks to the growers because within the frame of vertical coordination, links between farmers and buyers are becoming tighter to replace conventional open-market relations (Humphrey and Memedovic, 2006).

With regard to developing countries there is a demand for farmer organizations to engage in the improvement of market performance and to create an 'entrepreneurial culture' (Barham and Chitemi, 2009) in rural communities (Lundy et al, 2002; Markelova et al, 2009), because impeded access to markets is viewed as one of the major factors preventing smallholder farmers from prospering in the global economy.

\section{LITERATURE REVIEW}

Uttarakhand state has mainly two diverse agro-climatic benefactions named as the plains and the hills. Both the agro-climatic zones present different scenarios for agriculture, horticulture and the livestock. Mostly commercial agriculture is practiced in the plains and the farmers in the hills practice subsistence farming.

Mostly mixed cropping is common in the hilly areas while as seasonal single crops are grown in the plain areas. Most of the area of Uttarakhand state is under forests, waster bodies, snow deserts and rocky terrain, thus leaving only a small amount of land for cultivation purposes. Only 7.4 lakh hectare (about 14\%) area in Uttarakhand is available for cultivation purposes out of the total geographical area of around 56.72 lakh hectare. http://agriculture.uk.gov.in/files/Land Use 2009-10.pdf.

Irrigated land is freely available in the plains, with over $87 \%$ agricultural lands being irrigated as against a mere $10 \%$ in the hills. The seed replacement rate for the plains stands at $15-20 \%$, while for the hills it is 3-4\%. Productivity across the same crops also differs greatly between the hills and plains. In Uttarakhand more than 75 percent of the population depends on agriculture for their livelihood. The average size of holding in the state is less than 1 hectare with small and scattered land holdings. http://agriculture.uk.gov.in/., http://agropedia.iitk.ac.in/content/present-scenario-agriculture-uttarakhand.

Major crops grown in Uttarakhand are rice, wheat, sugarcane, maize, soybean, pulses and oilseeds. Major fruits grown are mango, litchi, guava, apricot, apple, plum. Vegetables grown in Uttarakhand are mostly potato, tomato, green pea, cauliflower, ginger and capsicum. 
In the hills the crops grown include wheat, paddy, mandua, ramdana and potato whereas in the plains the major crops are wheat, paddy, pulses and sugarcane. Though the population dependent on agriculture for their livelihood is about $80 \%$, the contribution of agriculture to the state's domestic product is only about $22.4 \%$.

In spite of this Uttarakhand is blessed with it's unique and rich bio-diversity. Under which over 175 rare species of aromatic and medicinal plants are found here. This gives producers a unique opportunity for diversification of activities within the primary sector. Small fragmented holdings, less irrigation facilities, tough terrain, adverse climatic conditions and non availability of productive germplasm ect are some of the important features of the agricultural producers in the hilly area of Uttarakhand. Above this, low return to their agricultural produces due to involvement of middleman between the seller and the consumer is a major cause of concern in this paper.

As objectives, the Mukteshwar Farmer Producer Company aims to support the farmers as follow: a) To provide an additional revenue model by creating a direct connection between producers and customers. b) To encourage increased participation of the individual farmer as an active shareholder in the company. c) To provide employment to the local people.

\section{DISCUSSIONS}

A Farmer producer companies can be seen as hybrids between private companies and cooperative societies. Producer companies aim to integrate smallholders into modern supply networks for minimizing transaction and coordination costs, while benefiting from economies of scale (Lanting, 2005). They are run and owned by farmers, financially facilitated by the government or donor agencies, and managed by professionals. Product and logistic requirements are especially high in the case of high-value agricultural products such as fresh fruits and vegetables, which makes transactions complex. Many case studies have shown, for a number of countries and product groups, that large retail chains tend to integrate transactions between the farm gate and the retail outlet vertically to ensure product quality and safety, traceability, and timely aspects of supply (Brown and Sander, 2007; Dolan and Humphrey, 2004; Key and Runsten, 1999; Shepherd, 2005).

A critical study was conducted for the establishment, working, current situation and challenges being faced by the Mukteshwar Farmer Producer Company. Though the company is formed by the farmers and for the farmers and it has huge market potential but there exist many operational as well as functioning issues.

Constitution of the company: 
Sustainability, Agri, Food and Environmental Research, (ISSN: 0719-3726), 9(2), 2021: 297-310 http://dx.doi.org/10.7770/safer-VONO-art2333

Formation of the FPC was a tough job for the volunteers as this concept was altogether a new initiative for the villagers within the age old, well established middleman's nexus in the village.

Anyhow, many of the progressive farmers of the area agreed to work within the framework of a FPC.

Finally, Mukteswar Farmer Producer Company was formed in the year 2014 after a chain of detailed discussions with the nearby farmers.

In the beginning Farmers had many apprehensions like who will give them loans? Who will sell their products? What prices will they get ? where will be the market for their produces ect ect. But all such doubts were gradually removed from their minds in the process of healthy dialogs with them.

As per the legal requirements for the formation of a FPO, 5 directors and 5 staff members were selected amongst the villagers after evolving a consensus through an open meeting.

To begin with no salary or honorarium was decided for the directors and the staff. Villagers extended their support for the formation of the FPC voluntarily and happily. In the initial year of its formation only 75 farmers joined hands for the FPC but after seeing the benefits to the FPC members, many more farmers willingly integrated themselves with the company.

Today Mukteswar Farmer Producer Company has

Over 700 farmers from nearby 41 villages of 3 developmental blocks.

19 women self help groups.

250 shareholders (Fig 1).
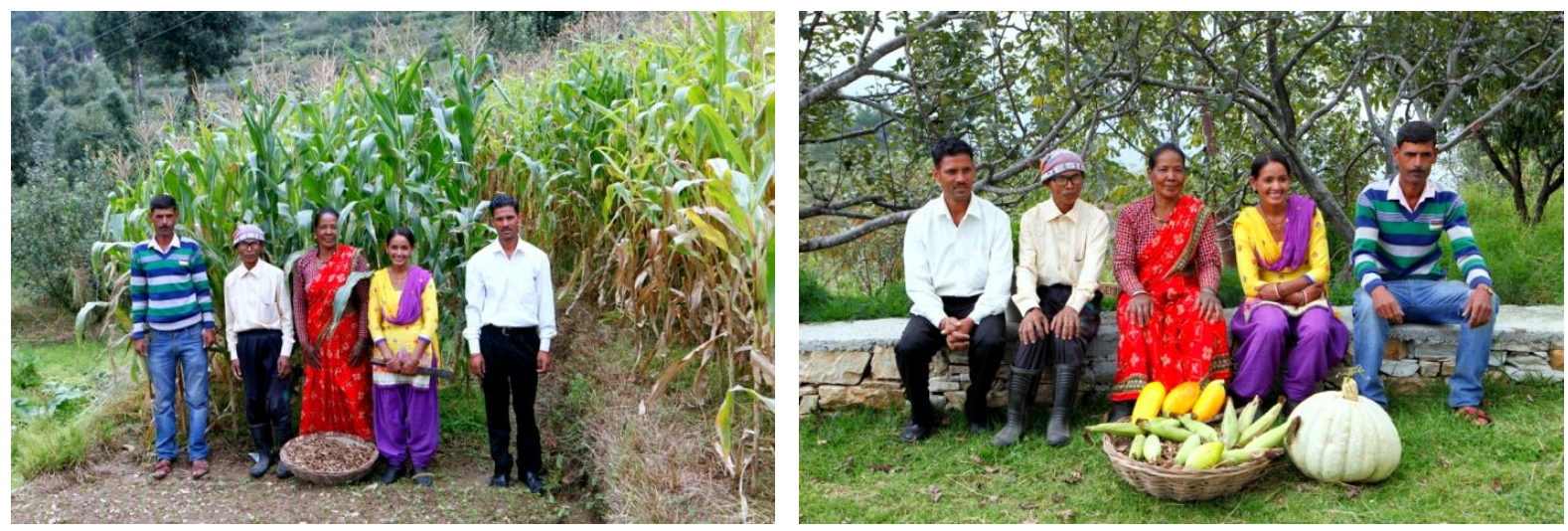

Farmers with their agricultural produce 
Sustainability, Agri, Food and Environmental Research, (ISSN: 0719-3726), 9(2), 2021: 297-310 http://dx.doi.org/10.7770/safer-VONO-art2333

- In totality, about $20 \%$ of the farmers within a radius of 5 to $6 \mathrm{kms}$, are now actively associated with the Farmer Producer Company. And 1 out of every 5 farmers in this area is now an active shareholder with the Mukteshwar Farmer Producer Company.

- It is worth mentioning here that seeing the overwhelming response of the farmers many well off nearby resident also extended their unconditional support to the FPC in the form of becoming a regular purchaser of their produces, suggesting new and better markets, helping in various legal matters, providing value addition equipments like packaging, sieve and strainer units and even attending their regular meeting (Fig.2, Table 1).

Table. 1. company's records, Mukteswar FPC has shown a record increase of total sales by 10 to 12 times during last 4 years.

\begin{tabular}{lc}
\hline Financial Year & Total sale proceed ( INR) \\
\hline FY 2016-17 & 21.1 lakhs \\
FY 2017-18 & 51 lakhs \\
FY 2018-19 & 1 crore \\
FY 2019-20 & 4 crores (targeted) \\
\hline
\end{tabular}
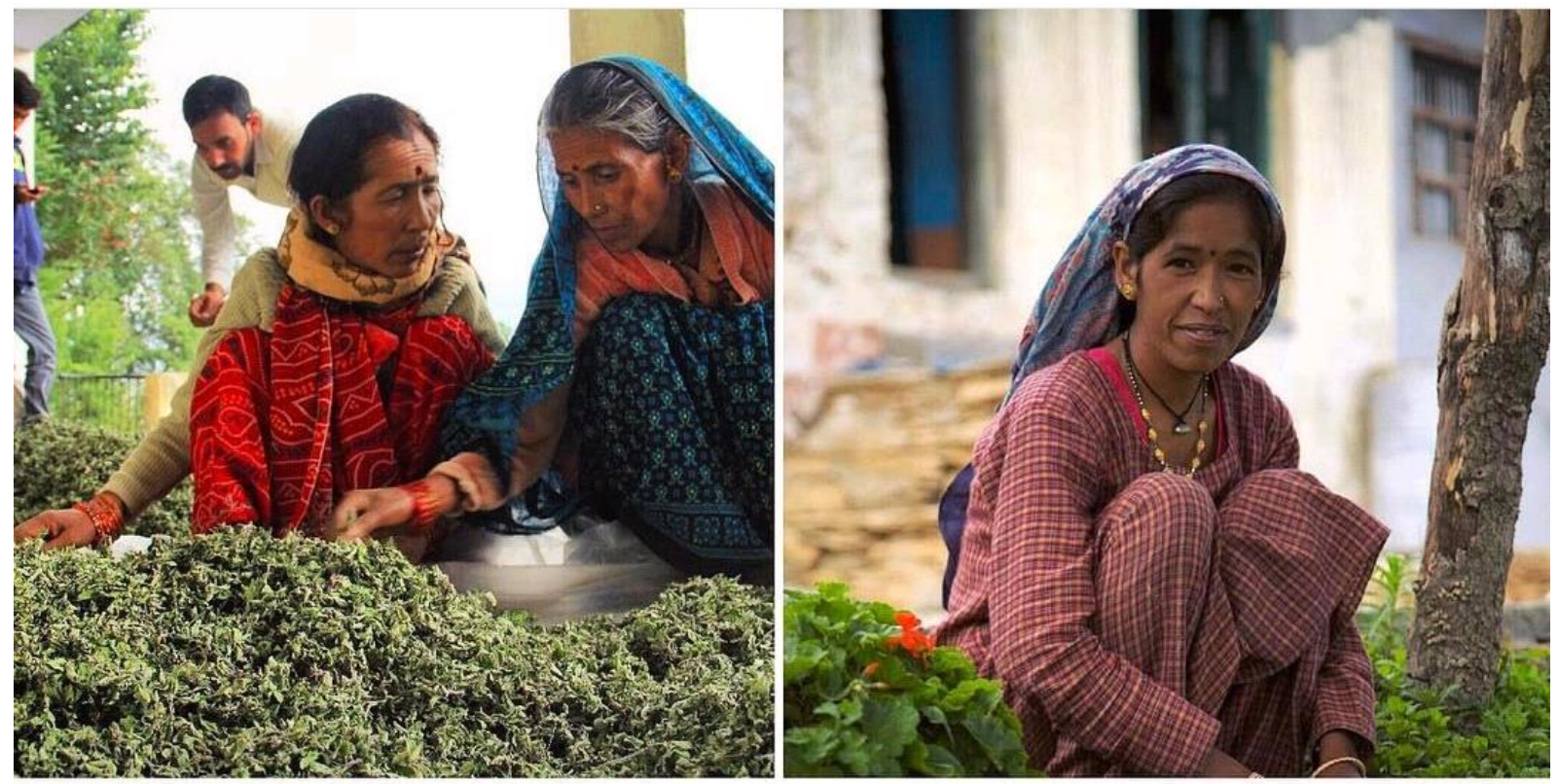

Fig. 2. Farmers doing value addition work to their agricultural produce 
Sustainability, Agri, Food and Environmental Research, (ISSN: 0719-3726), 9(2), 2021: 297-310 http://dx.doi.org/10.7770/safer-V0N0-art2333

Company's working:

All the enrolled farmers bring their agricultural and horticultural produce to a common collection centre. This centre is made on the road head to facilitate the transportation of raw as well as value added produce.

- The FPC focuses on adding value to farmer's produce by grading it, in order to create better value and acceptance in the bigger markets like Metropolitan cities.

- Value addition practice, helps get better rates for the produce. For Example all the fruits are classified in three categories. "A" grade fruits are bigger, flawless and much sweeter. It fetches much better prices as compared to " $B$ " or " $C$ " grade fruits which are a little inferior in color, taste and size as compared to " $A$ " grade fruits. than smaller or disfigured fruits.

- FLC also introduced the concept of proper packaging such as cardboard crate box with tray sheets as compared to wooden crate. This intervention ensures less damage in transportation and minimizes the risk of lower prices or even non-payment situation to the farmers.

- FPC not only deals in fresh fruit or fresh vegetable sale but also helps in processing the category "B" or " $C$ " produce into jam, jelly, pickle, squash and other preserves of daily use. This initiative provides much better prices to the producer even if the produce is of inferior quality.

- All above value addition works are facilitated by the FPC at its centre. Women self help groups are engaged in all such value addition works. Though these produces are seasonal in nature but after value addition their shelf life improves and the producers get around the year market.

- The most interesting feature of this FPC is that the company offers the producer a flat $15 \%$ higher rate to his produce as compared to the existing applicable wholesale market rates. This facility is being given to the producer so that the presence of a middleman could be totally eliminated from the system.

- Once the produce is graded or value added, it is packed in attractive and durable packages. Company helps the farmer to search a better market for the produce and finally gets the deal materialized.

- Company charges no money for it's support to the producer.

- Company gets income through the sale of those produces which the producer willingly sells to the company.

\section{BARRIERS}

Smallholder agriculture faces several constraints related to the small size of the operation. These include the inability to create scale economies, low bargaining power because of low quantities of marketable surplus, scarcity of capital, lack of market access, shortage of knowledge and information, market imperfections, and poor infra- 
Sustainability, Agri, Food and Environmental Research, (ISSN: 0719-3726), 9(2), 2021: 297-310 http://dx.doi.org/10.7770/safer-V0N0-art2333

structure and communications (Barham and Chitemi, 2009; Bienabe and Sautier, 2005; Mercoiret and Mfou'ou, 2006; Teshome et al, 2009).

- It's really challenging to break the shackle of the middleman in the villagers. These middlemen have become virtual members of their families and villagers think that they are their age old well wishers and helpers during hardship times.

- In order to maintain linkages with the known middlemen, many of the villagers are still giving larger portion of their produce to them and only 25 to $30 \%$ produce is being sold through FPC. This factor is prevailing mainly because of the past commitments made by the farmers with the middleman or with the wholesale purchasers.

- A critical factor that restricts farmers to actively approach FPC is the forced relationship between the farmer and the middleman or money lender. Regardless of the predacious nature of these moneylender and unreasonable interest rates, the farmer feel bound to him. Middle man or money lender often gives instant cash loan to the villager to meet his emergencies like family wedding, education, illness, natural calamity, house building and animal purchase, which makes farmer's strong emotional bend towards him (Table 2).

Table 2. A comparative study is shown below to highlight the working with a middle man and the FPC:

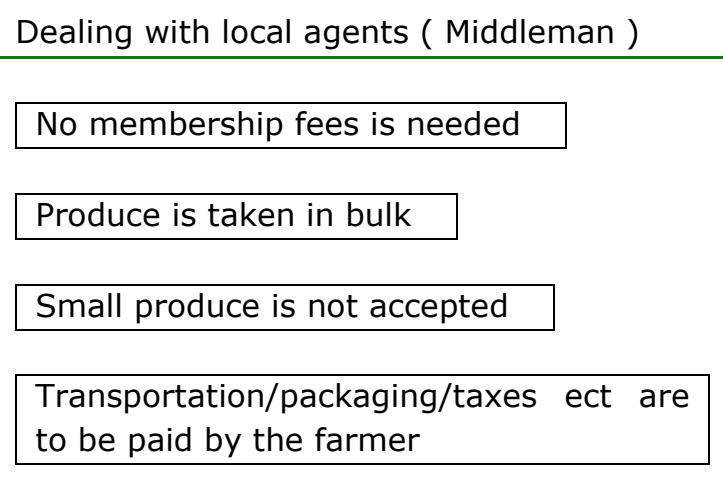

Dealing with FPC

Membership of Rs.500 is mandatory

Mainly graded produce is accepted

Small produce is always accepted

No added cost is taken from the farmer. Packing and transportation is facilitated by FPC

Receipt is always given

Receipt of the produce is not necessarily given

Payment schedule is not fixed

Gives Loans/financial assistance during off season
Payment schedule is fixed. Within 15 days farmer receives money.

At present loan/financial assistance is not provided as source of revenue of the FLC is very limited 
Sustainability, Agri, Food and Environmental Research, (ISSN: 0719-3726), 9(2), 2021: 297-310 http://dx.doi.org/10.7770/safer-V0N0-art2333

\section{KEY CHALLENGES}

While observing closely the staff, farmers and working of the FPC fallowing challenges seem to be addressed in future:

- FPC is far away from a corporate setup and quasi voluntary in nature. Staff employed is not paid and has become quite informal, due to which the field visits are not periodic and are not tracked.

- FPC lacks a structured long term plan with defined goals.

- When the season of fruits, vegetables and other agricultural produce approaches, farmer approaches the retailers, wholesalers and the FPC simultaneously. This creates lots of confusion before the FPC as the company is unable to make commitments before the prospective markets at metropolitan cities and big departmental stores.

- Data regarding farmer's land holding, type of produce raised, it's quantity and quality, time of harvest and handing over the produce ect are not available with the FPC. This creates hindrances before the FPC in futuristic planning.

- The focus on acquiring new and new farmers in the FPC gets diluted because of the absence of a paid and dedicated staff working in the company. During the seasonal rush it doesn't get much importance as the staff, themselves become very busy in their own lively hood activities like eco tourism, home stays, adventure sports, nature guide, sale of produces, road side shops, running taxies ect ect.

- Due to lack of funds, digitization is still lacking. If FPC gets more digitally and technically equipped then integration of inventories along with fiscal accounts , information regarding sellers and buyers, future forecasts for prospective crops, national and international trends and introduction to the newer agricultural technologies ect could be brought on a same e-platform for the benefit of the producers.

\section{ENABLERS}

Farmer Producer Company is performing it's work successfully for last 5 years. There are some strong reasons under which this company is hoping a revenue crossover of INR 5 to 10 crores in the coming years. Some of the enablers are mentioned as below:

- There are many willing and dedicated villagers in the company which extend their support voluntarily.

- Company directors are searching new and better markets for the producers and got success to get orders from metropolitan cities like Delhi and Mumbai.

- Company's value addition centre is increasing the worth of the produce brought by the villagers. This is being highly appreciated by the farmers.

- Company is gradually winning over the age old middleman's interference in agricultural produce sale business by providing better options to the producers.

- Company is planning to extend soft loans to the farmers once the kitty of the company gets sufficient money in it.

- Farmers selling their products through company are getting much better attention of various government schemes being launched in the village. 
Sustainability, Agri, Food and Environmental Research, (ISSN: 0719-3726), 9(2), 2021: 297-310 http://dx.doi.org/10.7770/safer-VONO-art2333

- Many well off nearby residents are joining various activities organized by the company. This factor is encouraging many more producers to join hands with the FPC.

- Increased production volumes are leading the organization to explore newer markets, such as Lucknow, Agra and Bangalore. As these markets have higher demand for seeds and fruits of Himalayan region like Himalayan region like peach, plum, berry, apple and apricot (Fig. 3).
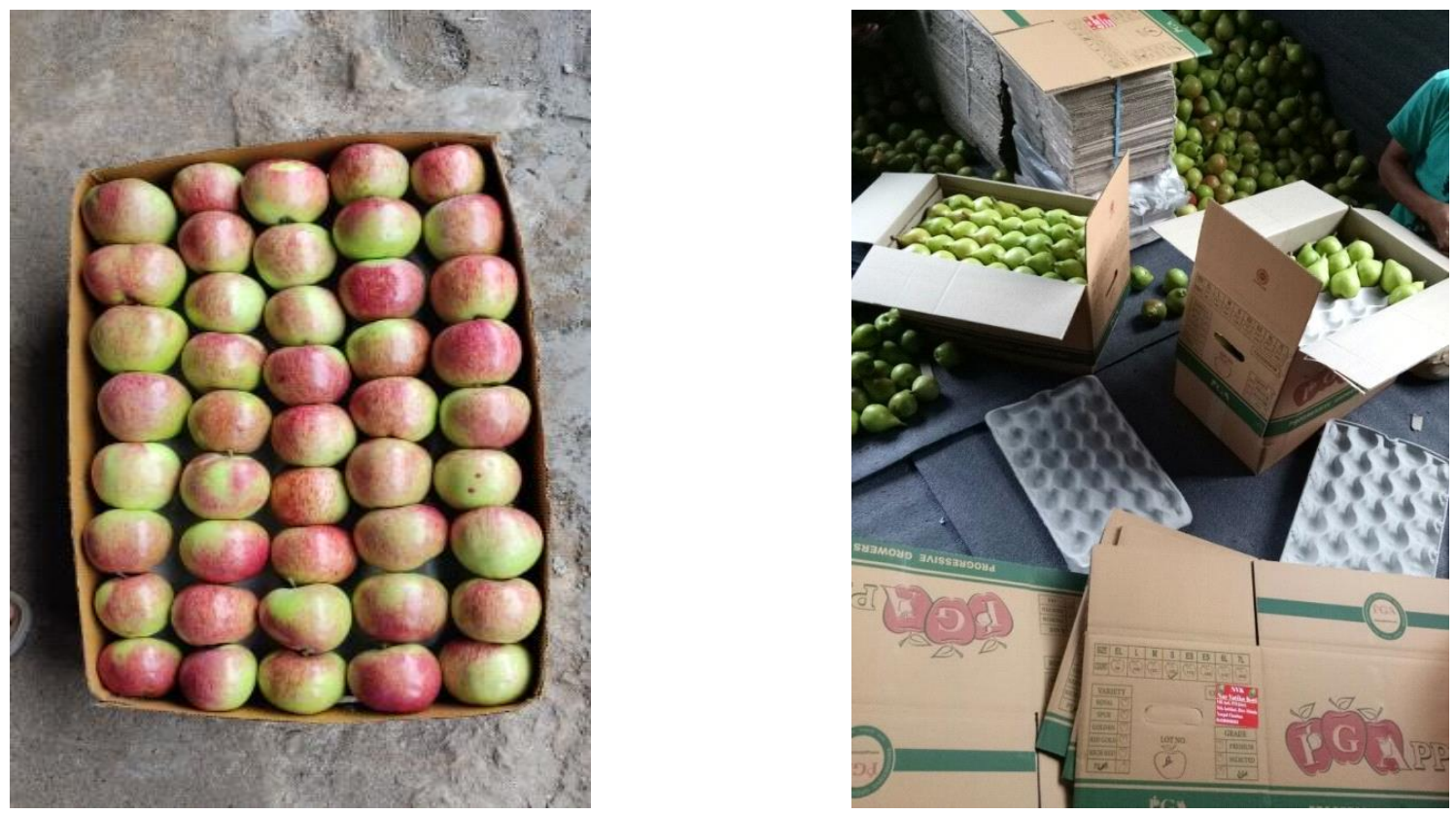

Fig. 3. Farmer's produce ready for sale

\section{FUTURE PLANS}

It is realized that the primary aim of the FPC is to provide a platform for better livelihood options to the local farmers, through the marketing of their local produce. This leads to analyses that the organization demanded Market expansion. This Factor can contribute to increase farmers from existing $20 \%$ to $50 \%$ in the years to come.

- The company also looks forward to educate the farmers with latest farming techniques as well as organic farming.

- Company will try to develop amongst villagers, more and more capabilities for selfsufficiency in their production, transportation and marketing.

- Company is also planning to extend pre-harvest support to the producer, through the sale of good quality seeds and provision of agricultural equipment on rent.

- Company is also moving in the direction to actively offer post-harvest support such as packing and grading of the produce of international standards. 
Sustainability, Agri, Food and Environmental Research, (ISSN: 0719-3726), 9(2), 2021: 297-310 http://dx.doi.org/10.7770/safer-V0N0-art2333

- In future company will be able to facilitate access to credit, through self help group loans.

- Once there are more farmers associated with the FPC, the next step for the organization is to setup a cold storage chain in the form of the solar refrigeration units so as to reach bigger and distant markets.

- The organization is also exploring and in talking terms with big and bulk buyers such as big bazar, nature's basket, mega marts etc.

- The company has also started proactive marketing -about transparency and other benefits of its programs.

- Company is developing a clear strategy for new farmer acquisition. New farmers develop stronger value proposition.

- Company has recently started taking produce, even if the farmer isn't a member. In such cases the membership fees is adjusted with the very first return the producer gets through sales.

- Company is also planning to provide health incentives to it's members through regular health checkups and medical insurance.

\section{NEW INITIATIVE TO PROTECT ENVIRONMENT}

FLC has recently started a very important program with the villagers. As the confidence level of the villagers is increasing day by day they are becoming more adoptable to the new initiatives taken by FPC. In this program villagers will bring a harmful forest bio residue at the value addition centre. This harmful forest bio residue is known as dry and fallen pine needles. Uttarakhand is predominantly rich in chir pine forest. It covers an area more than half a million hectare in Uttarakhand. Chir pine trees have a tendency of shedding its leaves annually in the months of February, March, April and May. These pine needles are highly inflammable and it carpets the whole forest floor. During summer months, either accidently or intentionally, it gets ignited. The ignition of the pine needles is very disastrous as it initiate forest fire. Once a forest fire is initiated, it causes some irreparable damages to the environment and the bio diversity of the area. FLC is planning to establish few manually operated bio briquetting machines at its value addition centre. This manual machine directly converts dry pine needles into briquettes of 30 to 50 grams. These briquettes are at par with coal as far as the calorific value is concerned. These briquettes have a good market in the industry. Interested Villagers will bring the dry and fallen pine needles at the value addition centre. Once the pine needle has reached the centre, villager will be paid an amount @2 Rupees a kg. At the centre, Villager will have a choice to convert the pine needles into briquette at his own. Once the briquettes are made, FPC will purchase the same @10 Rupees a $\mathrm{kg}$ and will sell it onward. This new initiative will become a source of additional revenue for the villagers. One of the writers of this paper has successfully designed and fabricated such manually operated bio briquetting machine. Such machines are already working in the nearby villages and becoming a source of earning money for the villagers. FPC will further think of developing a value chain for these briquettes and may even plan for additional value addition over the manufactured bio briquettes. Such initiative will certainly help in reducing the forest fire hazards in the near vicinity of the villages, as the fuel load on the forest floor will reduce (Fig. 4). 

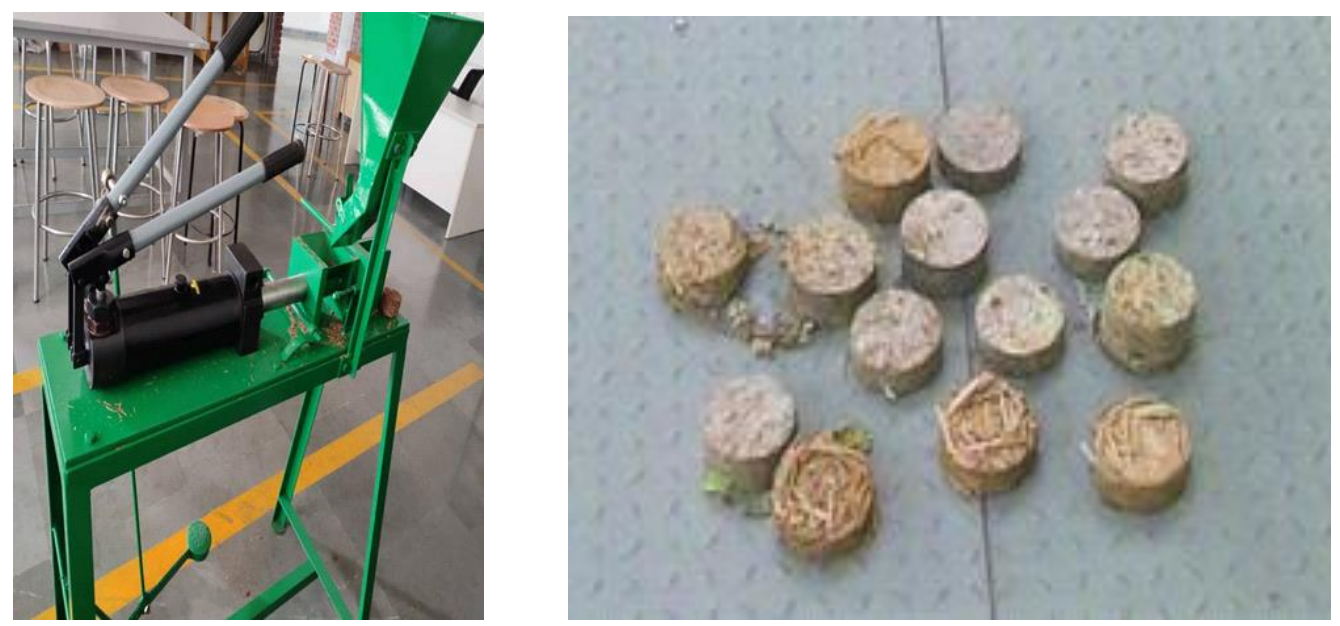

Fig. 4. Manually operated briquetting machine and pine needle briquettes

\section{CONCLUSION}

Hundreds of the farmers are getting benefits by being a part of the company. More and more villagers are getting interested in being an active share holder of the company. The formation of the Farmer Producer Company has changed the life as well as the thinking process of the producers in the area as now they are getting a much wider exposure of the market. Because of the formation of the Mukteshwar Farmer produce Company, villagers are getting following returns:

- Farmers are earning much higher profits.

- $\quad$ They get to learn new farming techniques.

- They categorize their produce and earn better as compared to the wholesale market.

- They also process even their " $\mathrm{C}$ " category produce which helps them earn in the off season.

- Villagers associated with the FPC are in the state of great mental satisfaction by directly selling to buyers at desired rates.

- Farmers are gradually getting free from the trap of middlemen.

- Many farmers are asking their second generation to continue farming and not to migrate when they see better returns on their field and home land.

In addition to this farmer's commitment towards environmental protection and saving the nearby forest area from the holocaust of forest fire in the chir pine forest is also remarkable. While being associated with the pine needle briquetting works, a villager can very easily earn good money by sale of the bio briquettes. It is worth to mention here that FPC provided a well established platform for the sale of the local produce, which in turn 
Sustainability, Agri, Food and Environmental Research, (ISSN: 0719-3726), 9(2), 2021: 297-310 http://dx.doi.org/10.7770/safer-V0N0-art2333

will be actively used for the sale of the bio briquettes made by the forest and agricultural waste. This dub tailing of the activity will not only increase the income levels of the villagers but also save the nearby forest from the danger of the forest fires.

\section{REFERENCES}

Bienabe E, Sautier D, 2005. The role of small scale producer's organizations in addressing market access', in Beyond Agriculture: Making Markets Work for the Poor Eds F R Almond,SDHainsworth,http://www.dfid.gov.uk/r4d/PDF/Outputs/CropPostHarvest/CPHP Intro.pdf, pp $69-85$.

Brown O, Sander C, 2007. Supermarket buying power: global supply chains and smallholder farmers', Trade Knowledge Network, International Institute for Sustainable Development, Winnipeg.

Barham J, Chitemi C, 2009. Collective action initiatives to improve marketing performance: lessons from farmer groups in Tanzania. Food Policy (34) 53 - 59.

Dolan C, Humphrey J, 2004: Changing governance patterns in the trade in fresh vegetables between Africa and the United Kingdom. Environment and Planning A (36) 491 - 509.

Humphrey J, Memedovic O, 2006. Global value chains in the agrifood sector. Working paper, United Nations Industrial Development Organization, Vienna.

KumarSharmaG, 2008. Producer companies: facilitating producers to do business in a better way, http://www.irma.ac.in/others/network past_issue.php? network_issue id $=84$

Key N, Runsten D, 1999. Contract farming, smallholders, and rural development in Latin America: the organization of agroprocessing firms and the scale of outgrower production. World Development (27) $381-401$.

Lanting $\mathrm{H}, 2005$. Building a farmer-owned company and linking it to international fashion houses under fair-trade arrangements. Paper presented at the International Conference on Engaging Communities, 14-17 August, Brisbane,Queensland, http://www.engagingcommunities2005.org/abstracts/S21lanting-h.html

Lundy M, Ostertag C F, Best R, 2002. Value adding, agroenterprise and poverty reduction: a territorial approach for rural business development. Paper presented at Globalization of Agricultural Research, Centro International de Agricultura Tropical, Rural Agro enterprise Development Project,Cali, http://www.ciat.cgiar.org/webciat/agroempresas/pdf/ value adding.pdf

Mercoiret M-R, Mfou'ou J M, 2006. Rural Producer Organizations (RPOs), Empowerment of Farmers and Results of Collective Action, The World Bank, Washington, DC.

Markelova H, Meinzen-Dick R, Hellin J, Dohrn S, 2009. Collective action for smallholder market access. Food Policy (34) 1 - 7.

Shepherd AW, 2005. The implications of supermarket development for horticultural farmers and traditional marketing systems in Asia. Paper presented at FAO/AFMA/FAMA Regional Workshop on the Growth of Supermarkets as Retailers of Fresh Produce, Food and Agriculture Organization, Rome

Teshome J TA, Hughes D, Chirwa E, Omiti J, 2009. The seven habits of highly effective farmers' organisations. Briefing, Future Agricultures, Brighton, Sussex. 
Sustainability, Agri, Food and Environmental Research, (ISSN: 0719-3726), 9(2), 2021: 297-310 http://dx.doi.org/10.7770/safer-V0NO-art2333

Received: 30 ${ }^{\text {th }}$ September 2020; Accepted: 21th October 2020; First distribution: 